\title{
ASSESSING PEDAGOGICAL APPROACHES TO FOSTER THE COMPREHENSION AND RETENTION OF NEW L2 SPANISH IDIOMS
}

\section{EVALUACIÓN DE PLANTEAMIENTOS DIDÁCTICOS PARA FAVORECER LA COMPRENSIÓN Y LA MEMORIZACIÓN DE LOCUCIONES IDIOMÁTICAS EN ESPAÑOL L2}

\author{
Clara Ureña Tormo \\ Universidad de Alcalá /Universidad Nebrija, España \\ clara.urena.tormo@gmail.com \\ https://orcid.org/0000-0002-7540-2931 \\ Julie DECONINCK \\ Vrije Universiteit Brussel, Bélgica \\ julie.deconinck@vub.be \\ https://orcid.org/0000-0002-1691-4785 \\ HÉLÈne STENGers \\ Vrije Universiteit Brussel, Bélgica \\ helene.stengers@vub.be \\ https://orcid.org/0000-0001-9999-492X
}

\begin{abstract}
This paper contains the experimental design of an empirical study that aims to assess the relative effectiveness of a number of pedagogical approaches designed to boost the comprehension of new L2 Spanish idioms and foster their retention. Building on a previous study (Ureña Tormo 2019), we suggest testing three pedagogical treatments, with two of them encouraging the participants to guess the meaning of the target idioms, before or after receiving information on their semantic motivation, and the
\end{abstract}

\section{Resumen}

Este artículo presenta el diseño experimental de un estudio empírico para facilitar la comprensión de locuciones españolas nuevas y favorecer su retención. Con el objetivo de mejorar y ampliar el alcance de un estudio previo (Ureña Tormo 2019), proponemos evaluar tres tratamientos pedagógicos distintos: dos de ellos invitan a los participantes a que adivinen el significado de las locuciones, antes o después de recibir información sobre su motivación semántica, y el otro se centra en inferir el significado a partir del

To cite this article: Ureña Tormo, Clara; Deconinck, Julie y Stengers, Hélène (2021). Assessing pedagogical approaches to foster the comprehension and retention of new 12 spanish idioms. ELUA, 35: 309-324. https://doi.org/10.14198/ELUA2021.35.15

Recibido: 22/03/2020, Aceptado: 14/09/2020

(C) 2021 Clara Ureña Tormo, Julie Deconinck, Hélène Stengers 
other one focusing on meaning inference from context. The target units are 15 Spanish idioms related to a range of topics and the participants are 90 English speaking learners of Spanish. The results that we obtain will allow for the assessment of the effectiveness of each pedagogical proposal, and will be compared to the ones obtained in Ureña Tormo (2019).

KEYWORDS: L2 Spanish; semantic motivation; meaning guessing; meaning inference; idiom. contexto. Las unidades objeto de aprendizaje son 15 locuciones españolas y los participantes se corresponden con 90 estudiantes de español cuya lengua materna es el inglés. Los resultados que se obtengan de este experimento permitirán evaluar la efectividad de cada propuesta didáctica y podrán compararse con los obtenidos en Ureña Tormo (2019).

PALABRAS CLAVE: español lengua extranjera; motivación semántica; adivinar significados; inferencia semántica; locución.

\section{INTRODUCTION}

Much of the recent research on Foreign Language Pedagogy has been dedicated to the learning and teaching of formulaic language (Boers, 2011). If effective language processing parses language as chunks, then mastery of formulaic sequences and multi-word units will be beneficial to L2 learners (Skehan, 1998; Wray, 2002). Indeed, research has shown that advanced language proficiency and effective communication skills are informed by the learner's knowledge of patterns of word combinations and prefabricated units (Boers \& Lindstromberg, 2008; Ellis, 2008). More generally, previous studies have attested to the benefits of learning L2 phraseology in terms of fluency, range of expression, and accuracy (Ellis, 2008; Littlemore, 2009; Meunier \& Granger, 2008). Consequently, experts in the field believe that L2 phraseology should have a central role in the process of teaching and learning a language.

Idiomatic expressions with figurative meaning (i.e. figurative idioms) are considered part of the phraseology of a language (e.g. ver los toros desde la barrera -in English, to sit on the fence-). Based on the idea that knowledge of L2 metaphors and figurative phrases also contributes to L2 mastery (Ellis, 2008; Littlemore \& Low, 2006; Skehan, 1998), the proposed study explores different ways of fostering the acquisition of L2 idiomatic expressions. More specifically, we suggest three pedagogical approaches for the learning of Spanish idioms to be tested in an empirical study with L2 Spanish learners. These teaching approaches contain tasks that involve meaning guessing -with or without prior knowledge of the semantic motivation of idioms- and meaning inference from context.

To some extent, the study suggested here is based on a previous one conducted by one of the authors of this paper (Ureña Tormo 2019), which also investigates the learning of L2 Spanish idioms, with the purpose of addressing some of its limitations and expanding its scope. Once the new experiment has been conducted, we aim to verify if the results obtained confirm the existing findings and thus provide a clear pathway to boosting the acquisition of L2 Spanish idiomatic expressions.

The sections below describe the experimental design, including its three research objectives, pedagogical treatments, and a set of general guidelines on the target participants, target units, data analysis, and potential pedagogical implications. After conducting the study, the results will allow for the comparison and assessment of the effectiveness of each pedagogical proposal. These findings will then be discussed in relation to the ones obtained in Ureña Tormo (2019). This will ultimately lead to evidence-based recommendations for the teaching of L2 idioms. 


\section{WHY FOCUS ON L2 IDIOMS?}

Idioms are fixed expressions with a figurative meaning that cannot be derived from their constituents' parts. Consequently, when L2 learners encounter new figurative idioms for the first time, they are likely to fail to guess the meaning correctly. Focusing on idioms is relevant for several reasons. Firstly, given that idioms are part and parcel of the phraseology of a language, it is important that learners are familiar with the most frequent idioms in order to communicate efficiently in the L2. Native speakers use idiomatic expressions in their daily life, so the acquisition of the most common L2 idioms is crucial due to their relevance in the process of communication (Penadés Martínez, 2012: 97).

Secondly, the Common European Framework of Reference for Languages (CEFR) (Council of Europe, 2018) clearly states that the teaching of L2 idiomatic expressions should be included in language syllabuses and the design of didactic materials. As regards the Spanish language, the Plan Curricular by the Instituto Cervantes (2006) also includes the teaching of Spanish idiomatic expressions as part of its teaching guidelines. In addition, the exams Diploma de Español Lengua Extranjera (DELE), organized by the Instituto Cervantes to assess the level of L2 Spanish proficiency, contain specific questions about L2 Spanish phraseological units (Penadés Martínez, 2012: 97).

Thirdly, given that idiomatic expressions exist in all languages, it seems reasonable to think that L2 learners are interested in learning the most popular idioms in the L2 (Leal Riol, 2011; Penadés Martínez, 2012). Apart from L2 learners, many foreign language teachers state in a survey conducted by Liontas (2013) that focusing on L2 phraseology in the classroom is important. The main reasons given by the respondents were the following: 1) phraseology is ubiquitous in everyday communication; 2) knowledge of L2 phraseological units has a positive effect on L2 learners' speech and writing, and 3) it improves strategic and cultural competence.

We do wish to provide one caveat at this stage though. For students up to intermediate level (e.g. B2 level), it is more important to understand these figurative expressions when encountered in texts or conversation than to be able to produce them, for it is only at the receptive level that they cannot be avoided, and they may impede successful communication as a result (Boers, personal communication). It is for this reason that the learning goal of the experimental study set out in this paper will only address receptive knowledge.

\section{PREVIOUS STUDIES}

When it comes to the teaching of L2 vocabulary and phraseology, meaning guessing is a common teaching and learning practice. Teachers' manuals and coursebooks very often include activities that invite students to guess the meaning of new words and phrases or to infer their meaning from a context (i.e. short texts or sentences). Specific exercises of this type have been found in L2 Spanish coursebooks (e.g.: Equipo Nuevo Prisma, 2017; Peláez \& Robles, 2017; Prieto de los Mozos, 2007). However, despite this widespread teaching practice, studies have shown that these types of activities may be error-prone and can potentially leave undesirable memory traces. Therefore, incorrect guessing or inferencing may actually have negative effects on the learning of new words (Carpenter et al., 2012; Laufer, 1997; Elgort, 2017; Warmington \& Hitch, 2014). The same outcomes have been found for the learning of new collocations and phrasal verbs (Boers et al., 2014; Strong \& Boers, 2019a, 2019b). 
A relevant approach in this respect may be provided by cognitive linguistics, which supports a usage-based approach to the study of language use and acquisition, and concerns itself with the non-arbitrary aspects of vocabulary and grammar. Within the framework of applied cognitive linguistics, focusing specifically on the learning of L2 vocabulary and phraseology, semantic elaboration has been defined as any mental operation directed to the meaning properties of words and phrases. In this light, Boers, Demecheleer and Eyckmans (2004) found that pedagogical approaches that provide information about the etymological origins of idioms are more beneficial for the learning of new L2 idioms than guessing their meanings. At the same time, the learning gains in their experiment were rather low in general, which leads us to think that neither of these techniques used in isolation is very effective.

Focusing on meaning recognition, Boers, Eyckmans and Stengers (2007) showed that the chances of identifying the figurative meaning of idioms were significantly boosted when learners had previously focused on their origins by guessing the source domain and then be presented with (corrective) feedback, compared to learners who did not elaborate and were asked to simply identify the meaning of the idioms. Similarly, Wang, Boers and Warren (2019) found that giving learners an explanation of the literal underpinning of idioms (literal-figurative link) enhances the chances of guessing their meaning correctly. In a previous experiment, Boers (2001) had already found that asking learners to speculate about the idioms' origins fosters their retention.

Next to semantic elaboration as a pathway to guessing or identifying the meaning of an idiom, context has proved to play a crucial role in the interpretation of new idioms (Cook, 2014; Kesckes, 2006). When it comes to the learning of idioms with a low degree of imageability, Boers and Demecheleer (2001) recommend relying on contextual clues to infer the meaning. In addition, Rohani et al. (2012) showed that, when inferring the meaning of new L2 idioms, learners are more likely to draw on contextual clues than to (attempt to) uncover the idioms' origins or to make a wild guess.

As regards Spanish idioms specifically, even though an increasing number of applied studies and pedagogical proposals have emerged for the teaching of L2 Spanish phraseology (e.g. Gómez González \& Ureña Tormo, 2015; Moreno Pereira, 2008; Sánchez Rufat, 2013; Szyndler, 2015; Timofeeva, 2013; Velázquez Puerto, 2018), empirical studies assessing the effectiveness of these pedagogical approaches are very limited. Against this backdrop, an initiative to fill this gap was the exploratory study reported in Ureña Tormo (2019) assessing the effectiveness of a cognitive linguistics-inspired teaching methodology to teach a set of 20 Spanish idioms related to 'speaking'. The findings showed that a pedagogical intervention in which the participants were directly presented with the meaning of the Spanish idioms and were then asked to reflect on their semantic motivation was more effective in terms of meaning recall compared to a pedagogical treatment in which students were invited to guess the meanings and were then presented with the idioms in context. In both conditions, from the beginning, the participants were provided with the literal translation in English (the participants' mother tongue) of the Spanish idioms. Although the treatment based on the semantic motivation of idioms yielded higher scores for the retention of idioms, the results were not statistically significant either in the immediate $(p=0.154)$ or one-week delayed post-tests $(p=0.382)$.

From the perspective of cognitive linguistics, we understand semantic motivation of idioms as the link between their form (the literal reading) and their actual meaning, the link 
being potentially based on conceptual metaphors and metonymies, conventional imagery, etymological data, and cultural knowledge associated with idioms (Lakoff, 1987). For example, the semantic motivation of the Spanish idiom irse por los cerros de Úbeda (literally, to go behind the hills in Úbeda), which means 'to get off the subject', can be attributed to: a) the metaphor that when someone deviates from a topic of conversation it is as if she deviates from his path -to get to a destination-, and b) a historical legend in which, during the conquest of the city of Úbeda (Andalusia), a general allegedly lost his way behind some hills to avoid fighting the enemy. This story has then provided the inspiration to denote a situation where you avoid talking about a touchy subject.

Despite making a significant contribution to L2 Spanish phraseology pedagogy, the study reported in Ureña Tormo (2019) included some aspects that could be optimized in a new experimental design. Firstly, the number of participants was low $(n=30)$. Secondly, all idioms had related meanings and some of them had similar forms, which could have been confusing and led to cross-associations between the target items. Thirdly, the participants received the literal translation in English of the Spanish idioms, and this may in turn have influenced the validity of the treatment in which learners were invited to guess the meaning of the idiom, for it is likely that participants established connections between the literal and the idiomatic meaning. We therefore propose to fine-tune the previous design and further build on current research on the effectiveness of cognitive linguistics-inspired techniques (e.g. knowledge of the semantic motivation of idioms) and meaning guessing tasks when it comes to the learning of new L2 Spanish idioms. Additionally, the scientific objectives and the scope of the research can be expanded upon by focusing on meaning comprehension in addition to meaning recall.

\section{SPECIFIC AIMS BASED ON PREVIOUS FINDINGS}

As stated, research has provided evidence that meaning-guessing tasks, despite them being a common pedagogical practice, may be error-prone. There is also evidence that knowledge of an idiom's origin increases the chances of guessing its meaning correctly and is beneficial for idiom retention. Elaborating on the semantic motivation of idioms has also proved to be beneficial for idiom retention over meaning-guessing. Furthermore, contextual clues have been shown to offer information that boosts learners' chances of making correct inferences about the meaning of target idioms.

These findings provide us with an opportunity to expand existing studies by comparing and assessing the merits of pedagogical interventions aimed at enhancing the learners' chances of guessing or inferring correctly, while at the same time reducing the risk of erroneous guessing that will negatively affect learning. More specifically, this paper aims to suggest pedagogical approaches based on the semantic motivation of idioms on the one hand, and contextual clues on the other hand, in a bid to 1) increase the likelihood of learners guessing or inferring the meaning of new L2 idioms correctly; 2) reducing the risk of error effects, and 3) revealing which approach is most effective in terms of idiom retention.

To this end, we propose the following pedagogical treatments (each treatment is described in detail in section 4.1.):

1 This definition has been taken from the Diccionario de locuciones idiomáticas del español actual. DiLEA (Penadés Martínez, 2019) and has been translated into English by the authors. 
- First treatment: providing learners with the semantic motivation of the idiom without any additional elaboration, then asking them to guess the meaning;

- Second treatment: presenting learners with the idiom in context and asking them to infer the meaning based on contextual clues;

- Third treatment: presenting learners with the idiom in isolation, then asking them to guess the meaning and finally providing the idiom's semantic motivation.

\subsection{Research questions}

This paper has three main scientific objectives, which are operationalized in three different research questions:

\subsubsection{First research question (RQ1)}

Firstly, we aim to assess to what extent cognitive linguistics-inspired approaches based on the semantic motivation of L2 idioms are more effective when it comes to enhancing the learner's chances of guessing their meaning correctly, compared to a pedagogical approach based on inferring the meaning of L2 idioms from contextual clues.

This objective yields the first research question (RQ1): Which treatment boosts learners' chances of guessing or inferring the meaning of L2 Spanish idioms correctly the most: relying on the semantic motivation of the idioms or relying on contextual clues? To answer this question, we recommend putting to the test two different pedagogical treatments. The first condition will be based on cognitive linguistics tenets, while the second condition does not.

In a first pedagogical treatment, learners are presented with the semantic motivation of an idiom and then asked to guess its meaning, followed by corrective feedback. For example, for the idiom ser uña y carne, the participants will read the following explanation of its semantic motivation: "Two or more people are said to be $u \tilde{n} a$ y carne based on the fact that nails are attached to the flesh and cannot be separated". Based on this, they will be asked to guess the meaning of the idiom and will then be provided with the correct meaning: 'to have a close friendship with somebody'. Informing learners of the idioms' semantic motivation (i.e. metaphors, etymology, etc.) contributes to making an informed guess as learners are provided with the actual motivation of the idiom, potentially being a treatment that is relatively little error-prone.

In a second pedagogical treatment, participants are shown the idiom in context and are invited to infer its meaning. After the meaning inference, they are presented with the correct meaning. The relevance of this condition is motivated by the fact that idioms normally appear within a context in real communication and teaching materials.

\subsubsection{Second research question (RQ2)}

Secondly, this paper aims to investigate if a pedagogical approach based on the semantic motivation of the target idioms is more effective for the retention of their meaning than a pedagogical approach based on inference from context. To address this objective, we suggest focusing on the learners' recall of the meaning of the idioms after a time delay from the intervention. The purpose is, therefore, to assess the mnemonic potential of each treatment. 
This leads us to the second research question (RQ2): which pedagogical approach is more beneficial in terms of meaning retention: receiving information about the semantic motivation before guessing the meaning, receiving information about the semantic motivation after guessing the meaning, or inferring the meaning from context?

It is commonly believed that immediate corrective feedback will override original memory traces (Kornell, Hays \& Bjork, 2009; Potts \& Shanks, 2014) - a belief that is widely applied in teaching practice- but there is evidence that incorrect guesses or inferences can lead to erroneous memory traces that resurface in post-tests even after the provision of corrective feedback (Elgort, 2017; Strong \& Boers, 2019a, 2019b). We believe, however, that the positive effects of corrective feedback may be enhanced by providing learners not only with the correct meaning of an idiom, but also with information about its semantic motivation. As such, we are interested in assessing a pedagogical approach that informs learners of the idioms' semantic motivation only after they have received corrective feedback on their meaning-guessing task.

For this reason, we have added a third pedagogical treatment to the experimental design, one in which learners are first invited to guess the meaning of idioms, followed by corrective feedback, and then provided with the semantic motivation of the idiom. We assume that participants in this condition will make the highest number of incorrect guesses as they do not receive any other input than the idiom itself before they start guessing. However, if learners are informed of the idioms' motivation after being informed of their actual meaning, it is conceivable that they try to find the specific link (metaphors, origin, cultural knowledge) between the given idiom and its (motivated) meaning. This may ultimately foster the retention of the idioms as the meanings are no longer perceived as arbitrary but motivated.

\subsubsection{Third research question (RQ3)}

RQ1 focuses on assessing the effectiveness of two methodological approaches to correctly guess/infer the meaning of L2 idioms that learners encounter for the first time. RQ2 investigates which pedagogical treatment fosters the retention of the idioms' meanings more effectively in the post-test. However, it does not devote explicit attention to the responses given by the learners when guessing or inferring the meanings of the target idioms during the pedagogical intervention. Therefore, it is necessary to go one step further to gauge which pedagogical approach is less error-prone, i.e. less likely to carry the risk of undesirable memory traces even after learners have received corrective feedback on any incorrect guesses/inferences.

By focusing on incorrect guesses or inferences during the pedagogical intervention, the third purpose is to assess which of the three pedagogical treatments put to the test will reduce possible error effects in the post-test. In other words, we aim to investigate if, for each treatment, there is a relationship between the nature and rate of incorrect responses in the meaning guessing/inferring tasks of new L2 idioms and the retention of these idioms in the post-test.

Therefore, the third research question (RQ3) is: When incorrect guesses/inferences occur during the treatment, which of the three pedagogical approaches lead to better meaning retention of the idioms after corrective feedback? At first sight, the third condition may not be particularly effective for correctly guessing/inferring the meaning of new idioms, but it may nevertheless still have potential to help learners retain their meanings as they are informed of the actual meaning immediately after the guessing task. 


\section{RESEARCH METHODOLOGY}

The methodological approach that best conforms to our three objectives requires developing one main experiment with three experimental treatments (or conditions), each of which tests the effectiveness of one pedagogical proposal. The three conditions have common characteristics as to their experimental design, and each is described below.

\subsection{Target participants}

Each treatment will include, at least, 30 English-speaking L2 Spanish learners enrolled at higher education institutions in Spain. This means that a minimum of 90 participants will take part in the experiment. Since the target idioms should not boast any congruence with their translation equivalent in the L1 (see below), we have opted to focus on English as the L1, meaning participants should be L1 English speakers. The participants in Ureña Tormo (2019) were also native English speakers, allowing for a comparison between the two studies. The participants have a B2 level of proficiency in Spanish according to the Common European Framework of Reference for Languages (CEFR). In order to make sure that the proficiency level of the three treatment groups is comparable, it will be necessary to administer a Spanish proficiency test prior to the experiment.

\subsection{Target units}

The target units to be included in the experiment are 15 Spanish idioms selected from the pedagogically oriented dictionary of L2 Spanish idioms by Penadés Martínez (2002), Diccionario de locuciones verbales para la enseñanza del español. Table 1 shows the target idioms together with their meaning and their translation equivalents in English. The definitions have been taken from the DiLEA (Penadés Martínez, 2019) and have been adapted and translated into English by the authors. The English equivalents have been obtained from the Collins Dictionary Spanish-English Online, except from the translation of the Spanish idiom perder los papeles, which comes from Linguee.es.

arrimar el hombro 'To help or to contribute'

to lend a hand

\begin{tabular}{ll}
\hline $\begin{array}{l}\text { bajar los humos } \\
\text { to take somebody down a peg (or two })\end{array}$ & 'To humiliate somebody that is arrogant' \\
\hline $\begin{array}{l}\text { caer del burro } \\
\text { to admit defeat }\end{array}$ & 'To admit defeat' \\
\hline $\begin{array}{l}\text { comerse el coco } \\
\text { to worry one's head }\end{array}$ & 'To be very worried' \\
\hline $\begin{array}{l}\text { estirar la pata } \\
\text { to kick the bucket }\end{array}$ & 'To die' \\
\hline $\begin{array}{l}\text { llegar a las manos } \\
\text { to come to blows }\end{array}$ & 'To physically fight with somebody' \\
\hline $\begin{array}{l}\text { perder los papeles } \\
\text { to freak out }\end{array}$ & 'To get angry' \\
\hline
\end{tabular}




\begin{tabular}{ll}
\hline $\begin{array}{l}\text { pinchar en hueso } \\
\text { to come up against a brick wall }\end{array}$ & $\begin{array}{l}\text { 'To fase an insurmountable obstacle while trying to } \\
\text { do something' }\end{array}$ \\
\hline $\begin{array}{l}\text { poner las orejas coloradas } \\
\text { to embarrass somebody }\end{array}$ & 'To embarrass somebody' \\
\hline $\begin{array}{l}\text { ponerse las botas } \\
\text { to strike it rich }\end{array}$ & 'To benefit financially from something' \\
\hline $\begin{array}{l}\text { quitar hierro } \\
\text { to play sth down }\end{array}$ & 'To downplay the importance of something' \\
\hline $\begin{array}{l}\text { sacarse de la manga } \\
\text { to make sth up off the top of one's head }\end{array}$ & 'To say something unrehearsed, unplanned' \\
\hline $\begin{array}{l}\text { salir del alma } \\
\text { to say something straight from the heart }\end{array}$ & 'To say something spontaneously' \\
\hline $\begin{array}{l}\text { ser uñ y carne } \\
\text { to be inseparable }\end{array}$ & 'To have a close friendship' \\
\hline $\begin{array}{l}\text { subirse a la parra } \\
\text { to get all high and mighty }\end{array}$ & 'To become conceited' \\
\hline
\end{tabular}

Table 1. Target idioms with their definitions and their English equivalents

The 15 idioms have been painstakingly selected on the basis of a range of criteria. For one, the idioms refer to different topics (e.g. emotions, linguistic activity, etc.) as research shows that presenting new words or phrases with similar meaning can lead to cross-associations (Erten \& Tekin 2008; Lázaro \& Hidalgo 2015; Papathanasiou 2008). Secondly, none of them are congruent with English (participants' L1) as congruent idioms would not pose a problem at the level of comprehension for our target participants. This basically means that, for example, the Spanish idiom coger el toro por los cuernos cannot be included as it has the same form in English -to take the bull by the horns. On the contrary, sacarse de la manga is a target idiom in the experiment as it is not congruent in English -to make sth up off the top of sb's head. Thirdly, all target idioms are opaque (i.e. their meaning cannot be derived from their constituents' parts). For example, the Spanish idiom tomar el pelo (in English, to pull sb's leg) cannot be interpreted based on the original meaning of the words tomar $+e l+$ pelo (take + the + hair), but the idiom has a totally different meaning: 'to make fun of sb'. Fourthly, all idioms have similar length (i.e. they are formed by three or four words), and they do not include words explicitly referring to cultural typical elements from Spain (e.g. irse por los cerros de Úbeda has not been included as Úbeda refers to a city in the south of Spain). As far as possible, all idioms have common characteristics so that their learning burdens are comparable, regardless of treatment.

\subsection{Process}

Prior to the experiment, we wish to carry out a pilot study with L2 Spanish learners that are L1 English speakers. Piloting will permit preliminary testing of the validity and feasibility of the experimental design reported here, in terms of: suitability of the input included in each condition; the number of target idioms; the time devoted to pre-test, treatment, post-test, etc. The pilot study may also reveal some concerns which have not been considered before, and it should reduce unanticipated problems. Adhering to the Computer-assisted language 
learning $(C A L L)$ approach to language learning, we will administer the experiment on computers. We will create an online platform with similar features to the one used in previous experiments (Boers, Eyckmans \& Stengers, 2007; Boers et al., 2009).

The experimental design involves three stages: 1) a pre-test; 2) the pedagogical intervention in which each group of participants will be subjected to one pedagogical treatment; and 3) a post-test.

\subsubsection{Pre-test}

A pre-test will be administered before the start of the experiment. In the pre-test the target idioms will be displayed in a table on the computer screen. The participants will be asked if they know the meaning of the idioms. If so, they must write down the meanings, but if not, they are requested to leave the answer blank in order to avoid guessing. The known idioms in the pre-test will also be included in the experiment, but responses given to these idioms in the post-test will be discarded as they do not reflect learning. The time allotted to the pre-test will be set to 10 minutes approximately, as this time proved sufficient in the study conducted by Ureña Tormo (2019)2.

\subsubsection{Pedagogical intervention}

After the pre-test, each group of participants will be subjected to one pedagogical treatment. Each condition consists of different steps that will appear on the computer screen as the participant clicks on the "Next" button. Again, on the basis of the experiment reported in Clara Ureña (2019), each idiom will be presented to the learners for 2 minutes in total, but the time devoted to take the pre-test and to display each idiom may be modified based on the results of the pilot study.

In Table 2 we set out in detail what is included in each condition.

\begin{tabular}{|c|c|c|c|}
\hline & Condition 1 & CONDITION 2 & Condition 3 \\
\hline STEP 1 & Display idiom & $\begin{array}{l}\text { Display idiom in context } \\
\text { (typographically highlighted) }\end{array}$ & Display idiom \\
\hline STEP 2 & $\begin{array}{l}\text { Give an explanation of the } \\
\text { semantic motivation }\end{array}$ & $\begin{array}{l}\text { Ask learners to infer the } \\
\text { meaning from context }\end{array}$ & $\begin{array}{l}\text { Ask learners to guess the } \\
\text { meaning }\end{array}$ \\
\hline STEP 3 & $\begin{array}{l}\text { Ask learners to guess the } \\
\text { meaning }\end{array}$ & $\begin{array}{l}\text { Give feedback with the } \\
\text { correct meaning }\end{array}$ & $\begin{array}{l}\text { Give feedback with the } \\
\text { correct meaning }\end{array}$ \\
\hline STEP 4 & $\begin{array}{l}\text { Give feedback with the } \\
\text { correct meaning }\end{array}$ & & $\begin{array}{l}\text { Give an explanation of the } \\
\text { semantic motivation }\end{array}$ \\
\hline
\end{tabular}

Table 2. Pedagogical approaches to be assessed in the study

2 Note that the study reported in Ureña Tormo (2019) targeted the learning of 20 idioms, which are five more than the ones included in this study. The number of target units has been reduced from 20 to 15 idioms as this number is considered more conductive to participant learning. 
Condition 2 includes fewer steps than the other conditions, but step 1 in this condition is more time-consuming than in the other cases as the idiom is inserted in a short text that the participants must read. To be clear, condition 3 should not be considered as an answer to RQ1 (Which treatment boosts learners' chances of guessing or inferring the meaning of L2 Spanish idioms correctly the most: relying on the semantic motivation of the idioms or relying on contextual clues?) for the following reason: if a participant subjected to this condition guesses an idiom's meaning correctly, it is very likely that they already knew that idiom in advance as we are dealing with non-congruent idioms and participants in this condition do not receive any treatment before the guessing task. In fact, when participants are invited to guess the meaning of an idiom in condition 3 they will probably give the same answer as in the pre-test, as there is no treatment between the two stages. To answer RQ2 (which of the three pedagogical treatments put to the test is more effective to retain the meaning of L2 Spanish idioms?) and RQ3 (which of these pedagogical treatments is less error-prone and yields higher learning rates after corrective feedback?) all three conditions will be included, as they are all relevant to these two research questions.

\subsubsection{Post-test}

One week after the pedagogical treatment, a meaning recall post-test will be administered. The post-test will be almost identical to the pre-test: the target idioms will also be displayed in a table on the computer screen and the participants will be asked to write down the meaning of the idioms they had learnt one week before. The participants will be given a maximum of 20 minutes to perform the post-test. This amount of time proved to be appropriate when the participants took a very similar post-test in Ureña Tormo (2019); however, the time allocated may be reduced after the piloting, since the number of target idioms has been reduced from 20 to 15 for the proposed study.

\subsection{Data analysis}

After the experiment, the responses given during the pedagogical intervention and in the post-test will be scored, and the results will be analyzed. For the purpose of answering RQ1, the number of correct and incorrect guesses/inferences for each idiom during the pedagogical intervention in each condition will be registered. By registering the total number of guesses/inferences in each condition, it will be possible to obtain the mean scores of correct guesses/inferences per treatment and then, compare the mean scores of correct guesses of conditions 1 and 2. (As already mentioned, condition 3 will not be considered to answer RQ1 because correct guesses in this condition would mean that the participants already knew the idiom as they do not receive any treatment before guessing the meaning). We propose to use the One-way ANOVA test to analyse the results, or Kruskall Wallis one-way variance test, in case of non-normal distribution.

Regarding RQ2, the number of correct and incorrect responses that the participants give for each idiom in each condition in the post-test will be registered. Thus, it will be possible to obtain the mean scores of correct responses in the post-test for each condition. Condition 3 is included in this analysis. Again, the One-way ANOVA statistical test (Kruskall Wallis one-way variance test, in case of non-normal distribution) will be applied; it will reveal which pedagogical treatment yields higher idiom retention scores. 
Finally, to answer RQ3 and assess which of the pedagogical treatments is less error-prone, the focus should be on the incorrect guesses/inferences that learners made during the pedagogical intervention in each condition in order to check if, after corrective feedback, they still lead to erroneous responses in the post-test or not. The appropriate statistical test is the mixed-effects logistic regression, in which the fixed effects are the participants' responses in the post-test, and the random effects are the participants guesses/inferences and the conditions.

\section{PEDAGOGICAL IMPLICATIONS}

This study has clear pedagogical implications for L2 learning and teaching, as it focuses on the potential to enhance the effectiveness of fairly common pedagogical practices for teaching L2 vocabulary and phraseology. On the basis of the results, it will be possible to formulate pedagogical recommendations as to whether knowledge of the semantic motivation of idioms is more effective to understand new L2 idioms than directing learner attention to the context in which they appear. These recommendations may be taken into account to improve teaching practice as well as the pedagogical tasks proposed in textbooks.

Apart from idiom understanding, this experiment also addresses idiom retention; therefore, the results may be useful to ascertain which of the following teaching techniques is more beneficial to foster the middle-term acquisition of idioms: either providing learners with information of the semantic motivation of idioms - prior or after the guessing- or presenting the idioms in context. And this regardless of the correct or incorrect meaning guessing/inference. These recommendations can complement the ones derived from Ureña Tormo (2019) regarding the benefits of elaborating on the possible link between an idiom and its meaning (i.e. semantic motivation) once the learner has already been provided with the idiom's meaning.

To some extent, the implementation of this experiment may also provide insight into the scaffolding of the learning process of L2 idioms by revealing the most beneficial time to add information of their semantic motivation: either before guessing their meanings or afterwards. The sequence factor may influence learning retention as well, since providing learners with the semantic motivation of idioms long before giving corrective feedback on their meaning (condition 1) may be useless in boosting the retention of an idiom, whereas giving information on the semantic motivation just after giving corrective feedback (condition 3 ) might actually be distractive when it comes to remembering the target meaning of the idiom.

In addition, this study has ecological validity, for the findings in Ureña Tormo (2019) suggest that meaning-guessing tasks are very popular among L2 learners, who enjoy hypothesizing on the possible meaning of L2 idioms. Interestingly, when the participants were asked about their preferred treatment when learning L2 Spanish idioms, their preferences were split evenly between the two conditions since both teaching methods (reflection on semantic motivation and meaning guessing on the basis of the literal translation) were appreciated. In this perspective, the L2 learning process can indeed be assumed to be a hypothesis testing process in which learners construct their own hypotheses about the language and then check them (consciously or unconsciously) against external feedback (Cook, 1985).

On top of that, the pedagogical implications of this study may be useful not only to address the teaching and learning of L2 Spanish idioms, but also in terms of its application to other types of expressions and other languages learnt as an L2. Given that cognitive linguistics accounts for the motivation of grammar and the lexicon, the pedagogical approaches suggested 
in this paper may be also useful for the learning of other target units like Spanish verbal periphrasis (i.e. verbal structures formed by a conjugated verb followed by an infinitive, gerund or participle) (e.g. andar + gerund; llevar + participle; romper $a+$ infinitive) or English phrasal verbs (e.g. cheer up; feel up; eat up; wind up). In both cases, it would be possible to implement a teaching approach for the learning of these units by focusing on their semantic motivation. As regards Spanish verbal periphrasis, one can rely on the original meaning of the auxiliary verbs (andar, llevar, romper) and look at how this contributes to the actual meaning of the verbal periphrasis when the auxiliary verbs appear together with the three verbal forms: infinitive, gerund, and participle. In the case of English phrasal verbs, it is important to focus on how the concepts associated with the adverb up motivate the actual meaning of the phrasal verbs; for example, up is related to the notion of 'happiness' as in cheer up and feel up, and 'completion' as in eat up and wind up (Kövecses \& Szabó, 1996: 347).

\section{CONCLUSIONS}

From this paper, we can draw two main conclusions on the acquisition of L2 Spanish idioms. Firstly, meaning-guessing and meaning-inference tasks are common pedagogical practices for the learning of L2 vocabulary and phraseology, but may be error-prone, regardless of the provision of corrective feedback. At the same time, knowledge of semantic motivation and etymological origin of idioms has proved to be beneficial for L2 idiom comprehension and retention. On this basis, we conclude that there is a need to enhance the chances of making correct hypotheses from the very beginning by promoting insightful learning (e.g. reflection on semantic motivation) and reducing potential erroneous memory traces that may impede proper retention.

Accordingly, this paper has laid the foundation for a new empirical study designed to assess two techniques based on cognitive linguistics insights which focus on the semantic motivation of idioms (treatments 1 and 3 ) and the merits of contextual information as a strategy to infer meaning (treatment 2). The effectiveness of each pedagogical approach has been addressed independently in previous studies (Boers, 2001; Boers, Demecheleer \& Eyckmans, 2004; Boers, Eyckmans \& Stengers, 2007; Cook, 2014; Kesckes, 2006; Rohani et al., 2012; Wang, Boers \& Warren, 2019); however, their relative effectiveness has not been assessed yet either for the learning of L2 English or L2 Spanish. This study is thus expected to be innovative and make further progress in the teaching of L2 Spanish idioms, as well as idioms in other languages.

As already mentioned, empirical studies on the effectiveness of pedagogical approaches for the learning of L2 Spanish idioms are very scarce. Thus, our second conclusion regards the need to start building up a body of experiments inspired by cognitive linguistics that test the effectiveness of any teaching proposal for the learning of L2 Spanish idioms, for which the study reported in Ureña Tormo (2019) provided a modest contribution. This present paper lays out how to fine tune that study and expand its research objectives -by not only addressing idiom retention, but also idiom comprehension-. In this way, the existing empirical research on the acquisition of L2 Spanish metaphors (e.g. Acquaroni Muñoz, 2008; Acquaroni Muñoz \& Suárez Campos, 2019; Masid Blanco, 2017) and L2 Spanish grammar (e.g. Cortés, 2015; Llopis-García, 2019; Sánchez Cuadrado, 2019) based on the tenets of cognitive linguistics will be expanded to include other types of units such as figurative idioms. 


\section{BIBLIOGRAPHIC REFERENCES}

Acquaroni Muñoz, R. (2008). La incorporación de la competencia metafórica (CM) a la enseñanzaaprendizaje del español como segunda lengua (L2) a través de un taller de escritura creativa: estudio experimental. $\mathrm{PhD}$ dissertation. Madrid: Universidad Complutense de Madrid.

Acquaroni Muñoz, R. \& L. Suárez Campos (2019). "El desarrollo de la competencia metafórica en el ámbito de la enseñanza-aprendizaje del español como segunda lengua". In Ibarretxe-Antuñano, I., Cadierno, T. \& A. Castañeda Castro (eds.). Lingüistica cognitiva y español LE/L2. London: Routledge, pp. 371-391.

Boers, F. (2001). "Remembering figurative idioms by hypothesising about their origin", Prospect, $16-3$, pp. 35-43.

Boers, F. (2011). "Cognitive semantics ways of teaching figurative phrases: an assessment", Review of Cognitive Linguistics, 9-1, pp. 227-261.

Boers, F., Demecheleer, M., Coxhead, A., \& S. Webb (2014). "Gauging the effects of exercises on verb-noun collocations", Language Teaching Research, 18, pp. 54-74.

Boers, F., Demecheleer, M. \& J. Eyckmans (2004). "Etymological elaboration as a strategy for learning idioms". In Bogaards, P. \& B. Laufer (eds.). Vocabulary in a second language: selection, acquisition and testing. Amsterdam / Philadelphia: John Benjamins Publishing Company, pp. 53-78.

Boers, F., Eyckmans, J. \& H. Stengers (2007). "Presenting figurative idioms with a touch of etymology: more than mere mnemonics?", Language Teaching Research, 11-1, pp.43-62.

Boers, F. \& S. Lindstromberg (2008). "How cognitive linguistics can foster effective vocabulary teaching". In Boers, F. \& S. Lindstromberg (eds.). Cognitive Linguistic Approaches to Teaching Vocabulary and Phraseology. Berlin / New York: Mouton de Gruyter, pp. 1-61.

Boers, F., Piquer Píriz, A. M., Stengers, H. \& J. Eyckmans (2009). "Does pictorial elucidation foster recollection of idioms?", Language Teaching Research, 13-4, pp. 367-382.

Carpenter, S. K., Sachs, R. E., Martin, B., Schmidt, K., \& R. Looft (2012). "Learning new vocabulary in German: The effects of inferring word meanings, type of feedback, and time of test", Psychonomic Bulletin \& Review, 19, pp. 81-86.

Collins. Collins Dictionary Spanish-English Online. $<$ https://www.collinsdictionary.com> (10-022020)

Cook, V. J. (1985). “Chomsky's Universal Grammar and Second Language Learning”, Applied Linguistics, 6-1, pp. 2-18.

Cook, E. (2014). Reading between the lines: the effect of context on idiom comprehension among speakers of L2 English living in the UK. MA dissertation. London: Birkbeck College.

Cortés, C. (2005). "Una aplicación empírica de la Gramática Cognitiva a las perífrasis verbales venir + gerundio, andar + gerundio e ir + gerundio", Revista Nebrija de Lingüística Aplicada a la Enseñanza de las Lenguas, 18. <https://www.nebrija.com/revista-linguistica/una-aplicacionempirica-de-la-gramatica-cognitiva-a-las-perifrasis-verbales.html $>$ (16-02-2020)

Council of Europe (2018). Common European Framework of Reference for Languages: Learning, Teaching, Assessment. Companion Volume with New Descriptors. Cambridge: Press Syndicate of the University of Cambridge.

Elgort, I. (2017). "Incorrect inferences and contextual word learning in English as a second language", Journal of the European Second Language Association, 1, pp. 1-11.

Ellis, N. C. (2008). "Phraseology. The periphery and the heart of language". In Meunier, F. \& S. Granger (eds.). Phraseology in Foreign Language Learning and Teaching. Amsterdam / Philadelphia: John Benjamins Publishing Company, pp. 1-14.

Equipo Nuevo Prisma (2017). Nuevo Prisma C1. Libro del alumno. Madrid: Edinumen.

Erten, I. H. \& M, Tekin (2008). "Effects of vocabulary acquisition of presenting new words in semantic sets versus semantically unrelated sets", System, 36-3, pp.407-422. 
Gómez González, A. \& C. Ureña Tormo (2014). Locuciones y refranes para dar y tomar. El libro para aprender más de 120 locuciones y refranes del español. Alcalá de Henares: Servicio de Publicaciones de la Universidad de Alcalá.

Instituto Cervantes (2006). Plan Curricular del Instituto Cervantes. Madrid: Biblioteca Nueva.

Kecskes, I. (2006). "On my mind: thoughts about salience, context and figurative language from a second language perspective", Second Language Research, 22, pp.219-237.

Kornell, N., Hays, M. J., \& R. A. Bjork (2009). "Unsuccessful retrieval attempts enhance subsequent learning”, Journal of Experimental Psychology: Learning, Memory, and Cognition, 35-4, pp. 989-998.

Kövecses, Z. \& P. Szabó (1996). "Idioms: a view from Cognitive Semantics”, Applied Linguistics, 17-3, pp. 326-355.

Lakoff, G. (1987). Women, Fire and Dangerous Things: what Categories Reveal about the Mind. Chicago: University of Chicago Press.

Laufer, B. (1997). "The lexical plight in second language reading: Words you don't know, words you think you know, and words you can't guess". In Coady, J. \& T. Huckin (eds.). Second Language Vocabulary Acquisition: A Rationale for Pedagogy. Cambridge: Caambridge University Press, pp. 20-34.

Lázaro, A. \& M. A. Hidalgo (2015). "Should EFL teachers present vocabulary in semantically related sets?", Porta Linguarum, 23, pp. 25-40.

Leal Riol, M. ${ }^{a}$ J. (2011). La enseñanza de la fraseología en español lengua extranjera. Estudio comparativo dirigido a estudiantes anglófonos. Valladolid: Universidad de Valladolid.

Linguee.es. <https://www.linguee.es/> (03-03-2020)

Liontas, J. I. (2013). "Educating educators about second language idiomaticity through action research", Iranian Journal of Language Teaching Research, 1-2, pp. 1-35. <http://files.eric.ed.gov/fulltext/ EJ1127431.pdf> (08-02-2020)

Littlemore, J. (2009). Applying Cognitive Linguistics to Second Language Learning and Teaching. Basingstoke / New York: Palgrave Macmillan.

Littlemore, J. \& G. Low (2006). "Metaphoric competence and communicative language ability", Applied Linguistics, 27-2, pp. 268-294.

Llopis-García, R. (2019). Gramática cognitiva y selección modal en la enseñanza del español LE/ L2. In Ibarretxe-Antuñano, I., Cadierno, T. \& A. Castañeda Castro (eds.). Lingüística cognitiva y español LE/L2. London: Routledge, 255-273.

Masid Blanco, O. (2017). "La metáfora lingüística en español como lengua extranjera (ELE). Estudio pre-experimental en tres niveles de competencia”, Porta Linguarum, 27, pp. 155-170.

Meunier, F. \& S. Granger (2008). "Phraseology in language learning and teaching. Where to from here?". In Meunier, F. \& S. Granger (eds.). Phraseology in Foreign Language Learning and Teaching. Amsterdam / Philadelphia: John Benjamins Publishing Company, pp. 247-252.

Papathanasiou, E. (2008). "An investigation of two ways of presenting vocabulary", ELT Journal, 63-4, pp. 313-22.

Peláez, S. \& S. Robles (coords.) (2017). Método de español 5: español lengua extranjera C1-C2. Madrid: Grupo Anaya.

Penadés Martínez, I. (2002). Diccionario de locuciones verbales para la enseñanza del español. Madrid: Arco / Libros.

Penadés Martínez, I. (2012). "Didáctica de la fraseología y de la paremiología". In Ortiz Álvarez, M.a L. (org.). Tendências actuáis na pesquisa descritiva e aplicada em fraseologia e paremiologia. Anais. Volume I. Campinas: Pontes Editores, pp. 91-117.

Penadés Martínez, I. (2019). Diccionario de locuciones idiomáticas del español actual. DiLEA. $<\mathrm{http}: / /$ www.diccionariodilea.es $>(05-03-2020)$

Potts, R., \& D. R. Shanks (2014). "The benefit of generating errors during learning", Journal of Experimental Psychology: General, 143, pp. 644-667. 
Prieto de los Mozos, E. (dir.) (2007). Español ELElab Universidad de Salamanca C1-C2. Salamanca: Ediciones Universidad de Salamanca.

Rohani, G., Ketabi, S. \& M. Tavakoli (2012). “The Effect of Context on the EFL Learners' Idiom Processing Strategies", English Language Teaching, 5, pp. 104-114.

Rufat, A. \& F. Jiménez Calderón (2019). "Vocabulario". In Muñoz-Basols, J., Gironzetti, E. \& M. Lacorte (eds.). The Routledge Handbook of Spanish Language Teaching: metodologías, contextos y recursos para la enseñanza del español L2. Oxon, New York: Routledge, pp. 229-242.

Sánchez Cuadrado, A. (2019). Foco en la forma y traducción pedagógica en español LE/L2: el caso de la pasiva perifrástica. In Ibarretxe-Antuñano, I., Cadierno, T. \& A. Castañeda Castro (eds.). Lingüística cognitiva y español LE/L2. London: Routledge, pp. 300-321.

Skehan, P. (1998). A Cognitive Approach to Language Teaching. Oxford: Oxford University Press.

Strong, B., \& F. Boers (2019a). "The error in trial and error: Exercises on phrasal verbs", TESOL Quarterly, 53, pp. 289-319.

Strong, B., \& F. Boers (2019b). "Weighing up exercises on phrasal verbs: retrieval versus trial-anderror practices", The Modern Language Journal, 103-3, pp. 562-579.

Timofeeva, L. (2013). "La fraseología en la clase de lengua extranjera, ¿misión imposible?", Onomázein, 23, pp. 320-336.

Ureña Tormo, C. (2019). La enseñanza de las unidades fraseológicas desde la Lingüística cognitiva. $\mathrm{PhD}$ dissertation. Alcalá de Henares: Universidad de Alcalá.

Velázquez Puerto, K. (2018). La enseñanza-aprendizaje de fraseología en ELE. Madrid: Arco / Libros.

Wang, X., Boers, F. \& P. Warren (2019). "Using literal underpinning to help learners remember figurative idioms: Does the connection need to be crystal-clear?". In Piquer-Píriz, A. M. \& R. Alejo-González (eds.). Metaphor in Foreign Language Instruction. Berlin: Mouton de Gruyter, pp. $221-240$

Warmington, M., Hitch, G. J., \& S. E. Gathercole (2013). "Improving word learning in children using an errorless technique", Journal of Experimental Child Psychology, 114, pp. 456-465.

Wray, A. (2002). Formulaic Language and the Lexicon. Cambridge: Cambridge University Press. 